\title{
The tension between emotive/aesthetic and analytic/scientific motifs in the work of amateur visual documenters of Antarctica's Heroic Era
}

\author{
Pat Millar \\ University of Tasmania (Patricia.Millar@utas.edu.au)
}

Received June 2016; first published online 9 March 2017

ABSTRACT. Visual documenters made a major contribution to the recording of the Heroic Era of Antarctic exploration. By far the best known were the professional photographers, Herbert Ponting and Frank Hurley, hired to photograph British and Australasian expeditions. But a great number of images - photographs and artworks were also produced by amateurs on lesser known European expeditions and a Japanese one. These amateurs were sometimes designated official illustrators, often scientists recording their research. This paper offers a discursive examination of illustrations from the Belgian Antarctic Expedition (1897-1899), German Deep Sea Expedition (1898-1899), German South Polar Expedition (1901-1903), Swedish South Polar Expedition (1901-1903), French Antarctic Expedition (1903-1905) and Japanese Antarctic Expedition (1910-1912), assessing their representations of exploration in Antarctica in terms of the tension between emotive/aesthetic and systematic analytic/scientific motifs. Their depictions were influenced by their illustrative skills and their 'ways of seeing', produced from their backgrounds and the sponsorship needs of the expedition.

\section{Images of the Heroic Era of Antarctic exploration}

Illustrators made a major contribution to the recording of the Heroic Era of Antarctic exploration, providing visibility to the climactic peak of achievement in the period from around 1895 to 1922 when the continent was explored, its coastline and topography mapped, and the South Pole reached (Andrews 2007). Widely displayed on lecture tours and in newspapers and magazines in order to raise funds for potential future expeditions (Barr 1997), their images played a vital role in sustaining the Heroic Era and in keeping its achievements dramatically alive in the public consciousness for the hundred years since (Yusoff 2010). It is, of course, understandable that the fine work of the professional photographers Herbert Ponting (1870-1935) and Frank Hurley (1885-1962), English and Australian professionals on expeditions by Robert Falcon Scott (British Antarctic Expedition 1910-1913), Douglas Mawson (Australasian Antarctic Expedition 1911-1914) and Ernest Shackleton (Imperial Trans-Antarctic Expedition 1914-1917) attracts most attention (on Ponting: Arnold 1971; Savours 1974; Riffenburgh \& Cruwys 1998; Riffenburgh and others 2004; Lane and Martin 2006; on Hurley: Thomas 1990; Ennis 2002; McGregor 2004; works by both photographers were featured in the Heart of the Great Alone Exhibition in the Queen's Gallery, Buckingham Palace, London, 2011-2012, Le grand blanc [The great whiteness] exhibition at the Atelier d'Artistes gallery, Paris, in 2010 and in Die Welt in Schwarz-Weiss [The world in black and white] exhibition, Livona, Italy, in 2012). But Ponting and Hurley were not the only ones to produce memorable images of the Heroic Era. Illustrators on Belgian, German, Swedish, French and Japanese expeditions also achieved important work.

The developing technology of photography would come to dominate illustration, but some work continued to be produced by artists. Natural science illustrators are artists in the service of science, using scientifically informed observational, technical and aesthetic skills to portray a subject accurately (Hodge 2003: xi). Illustrators were expected to communicate accurate information while applying artistic skills of design, drawing and painting. Like art, photography, though commonly associated with objectivity, is a cultural practice with its own codes and conventions, and choices of selection, framing and personalisation are largely subjective (Sturken and Cartwright 2001). There is an inevitable tension between emotive/aesthetic and analytic/scientific motifs in the work of Heroic Era illustrators as their gazes alternate between those informed by emotive and aesthetic interests on the one hand, and on the other hand rational scientific purposes and interest.

Printed engravings of paintings done by polar expeditioners were an early source promoting the Arctic in the popular imagination via illustrated weeklies (David 2000). Photography was used to record expeditions from soon after the medium was invented in 1839, despite the challenges of climate and environment. Probably the earliest Arctic photographs that survive are from Sir Edward Belcher's 1852-1854 expedition to search for the ill-fated Sir John Franklin expedition of 1845-1848 (Wamsley and Barr 1996).

In the Antarctic, Andrews (2007) has presented a detailed artistic assessment of the work of illustrators of exploration from the earlier days of drawings and watercolour to the emergence and eventual dominance of photography. On Captain James Cook's exploratory and scientific voyage searching for the southern continent (1772-1775), William Hodges and George Forster were official artists, producing work which set a standard followed by subsequent artist-illustrators. On James Clark Ross's British voyage of 1839-1843, John Edward Davies produced amateur watercolours of landscapes and 
activities. By the end of the nineteenth century, photography's value for recording events, landscapes and people had been established (Newhall 1972), and photography was increasingly used to illustrate progress in natural science and geography (Wilder 2009), which was the most often professed motivation for Heroic Era Antarctic exploration.

Visual documentation played an important role in representations of the world, structuring understandings of remote and largely inaccessible regions such as Antarctica (Yusoff 2010). As Pyne (1986: 232) has written, 'To enter Greater Antarctica is to be drawn into a slow maelstrom of ice.' Along with accounts of exploration, images of this ice entered national discourses, enabling them to operate within cultural memory, the way people collectively form understandings of the past (Barwell 2007).

\section{Ways of seeing}

Images contain textual arrangements and discursive practices, producing multi-layered cultural messages in which creator, subject and viewer all play their roles, and which rely on cultural and historical contexts and on experiential knowledge (Barthes 1977). Images are dynamic sites at which many gazes and ways of seeing intersect (Lutz \& Collins 2003). Just as illustrators' gazes are mediated by cultural, social and historical contexts, so are the gazes of viewers of the images.

To look is an act of choice ... We never look at just one thing; we are always looking at the relation between things and ourselves (Berger 1972: 8-9).

Every image represents a way of seeing which 'is affected by what we know or what we believe' (Berger: 107). But the kinds of images brought back to audiences at home depended also on specific expeditionary needs and those of various governments and other sponsors.

The notional audience for images of exploration was, in the first instance, the geographical/scientific one for which the exploration was being documented and recorded. Some illustrators had future publications in mind. All were thinking of funding bodies, government and nongovernment, present and future. In this context they also had in mind the wider public, whose support would inspire the funding of further expeditions.

\section{Ice and the cultural imaginary}

Within the oft reproduced images of polar exploration certain motifs occurred which became taken for granted. Arguably the most striking of these is that of ships in the ice, an image evoking the romantic aspect of powerful nature, relentless ice masses pressing in on small ships (Barr 1997). Sir John Franklin's Terror and Erebus (1845), Nils Adolf Nordenskjiold's Vega (1878-1879) and Nansen's Fram (1893-1896) are among many striking images that survive of ships in the Arctic ice.

Images of icebergs and ice occur many times in visual documentation of the polar regions. These images became embedded in the cultural imaginary, the "networks interlinking discursive themes, images, motifs and narrative forms that are publicly available at a given culture at any one time, and articulate its psychic and social dimensions' (Dawson 1994: 48). In stories of polar exploration, the cultural imaginary involved the masculinity, adventure and nationalism which had become associated with images of the Arctic and Antarctic. Naturalisation of ice and iceberg motifs enabled readers and viewers immediately to construe its discursive context (Ryall and others 2010).

This paper examines illustrations of ships in the ice from the Belgian Antarctic Expedition (1897-1899), German Deep Sea Expedition (1898-1899), German South Polar Expedition (1901-1903), Swedish South Polar Expedition (1901-1903), French Antarctic Expedition (1903-1905) and Japanese Antarctic Expedition (19101912).

\section{Ice bound and iceberg: Belgian Antarctic, German Deep Sea and German South Polar expeditions}

Scientific progress was the most often professed motivation for Heroic Era Antarctic exploration. The Antarctic was a vast unknown, and the further development of geography and natural sciences was believed to depend on its exploration. The first three images examined in this paper are from expeditions where the natural sciences were uppermost in the minds of their creators.

\section{Belgian Antarctic Expedition: Henryk Arçtowski}

Belgica's enforced year in the Antarctic ice in 1898 had a heavy impact on the expedition members, requiring them to deal with isolation more intense than that experienced by most explorers. Photographs of the Belgica taken by Frederick A. Cook (Millar 2015) set a tone of foreboding for the Heroic Era in Antarctica. A lesser known photographer on the voyage was Henryk Arçtowski.

Two years before the Belgian Antarctic Expedition, its leader Adrien De Gerlache appointed the Polish exile Henryk Arçtowski (1871-1958) scientific deputyleader and geologist, meteorologist and oceanographer (Machowski 1998a). Arçtowski, described by Roald Amundsen as 'an all-round man' (1912: 19), was well immersed in south polar issues (Raraty 1998). In preparation for the expedition he undertook studies in glaciology in Switzerland, which gave him his first field experience in an ice environment. He also studied oceanography in England, consulting with scientists who had been on the Challenger expedition (1872-1876) (Machowski 1998b). He assisted De Gerlache in recruiting scientists for the expedition, and in lecturing to raise funding for it (Machowski 1998a). In a contrasting field, Arçtowski had a friendship with Ukrainian artist Ivan Pokhitonov, and through this he had acquired an appreciation of the subtleties of landscape painting (Arçtowski 1901: 163). His way of seeing may be deduced as scholarly and scientific, influenced by his practical experience in the field on the Swiss glaciers but also by his interest in art.

Among papers on the expedition's scientific findings authored by Arçtowski, there are photographs, mostly 


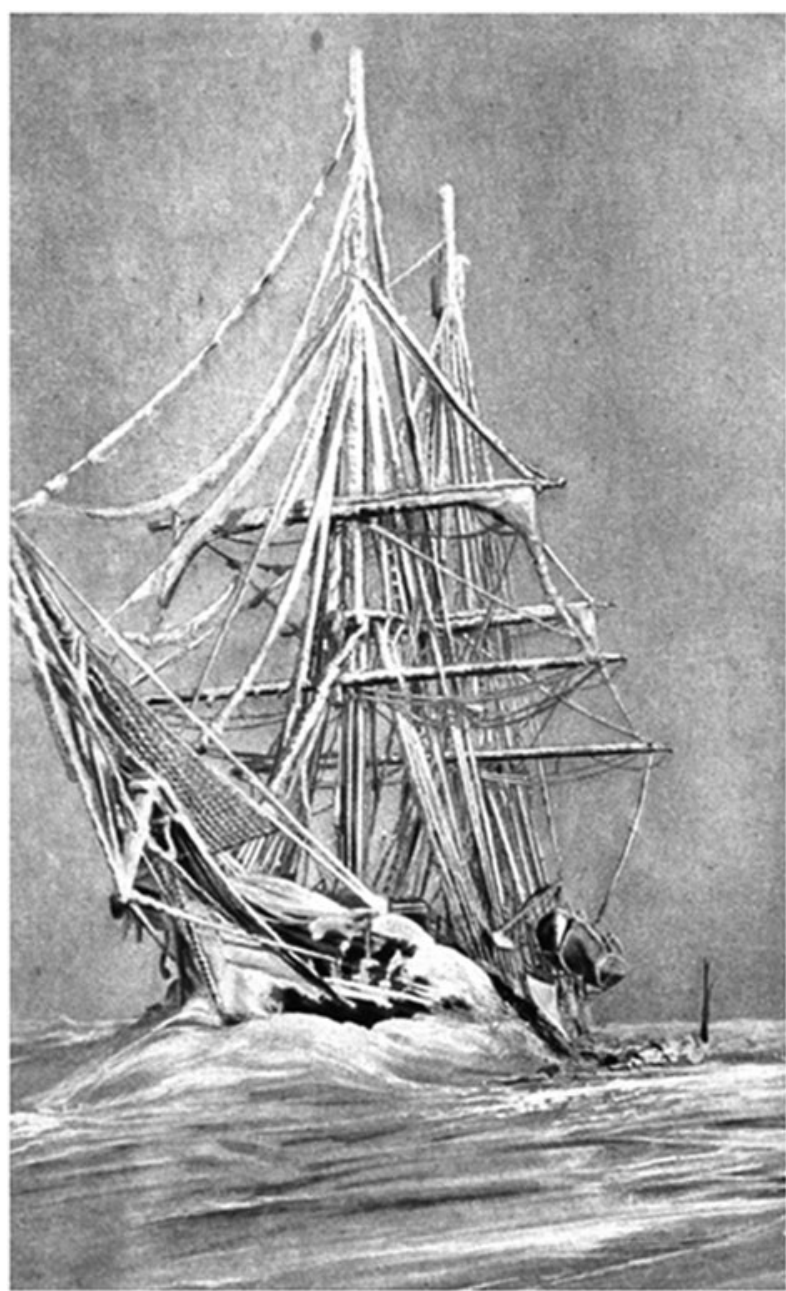

Fig. 1. Belgica soon after return of sun (Photo: $\mathrm{H}$. Arçtowski)

(In H. Arçtowski 1908: 33)

taken by himself, selected to illustrate aspects of the text. Some of these have a power that enables them to stand alone as striking depictions.

Arçtowski used the photograph in Fig. 1 in his report on changing ice conditions after the return of the sun (Arçtowski 1908). But the image also works effectively as art. The low angle image of the ice-shrouded ship, the bow almost front on to the viewer and damaged by collision with an iceberg, is a dramatic one, the upper structure seeming to strain upward in a vain attempt to get free from the ice. The image situates the viewer in a responsive attitude of awe as he or she contemplates the predicament of the expedition. It evokes myths of ghost ships, and foreshadows the photographs of the Endurance in the ice which Frank Hurley would take in 1915. Arçtowski's gaze as he looked through his camera lens was informed by rational scientific purpose and interest, and he used the photograph in a scientific paper, illustrating the crust of frost and ice on the rigging and the characteristics of the ice and snow around the ship. But emotive and aesthetic interests also informed that gaze, and may even be said to predominate.

\section{German Deep Sea Expedition: Friedrich Winter}

The German Deep Sea Expedition (1898-1899) was an oceanographic voyage in the Atlantic and Indian oceans, led by zoologist Professor Carl Chun in the steamship Valdivia. It spent almost four weeks in the sub-Antarctic, achieving a farthest south position of $64^{\circ} 15$ Ś, investigating chemical, zoological and physical aspects of the ocean. The expedition included a scientific draughtsman, artist and photographer, Friedrich Wilhelm Winter, who had signed on voluntarily (Chun 1903: 17). The inclusion of artists had been a feature of German Arctic expeditions in 1869-1870 and 1872-1874, but the Deep Sea Expedition would be the only German expedition to the Antarctic to have one on board.

Friedrich Wilhelm Winter(1878-1917) had vocational training in his father's nationally renowned printers in Frankfurt-am-Main, which specialised in the production of lithographs to illustrate mostly scientific works (Senckenberg Nature Research Society 1918), but his interest in natural science and his artistic talent led him to science illustration. He was only 20 years of age when he joined the Deep Sea Expedition, and appears to have been previously untraveled. His 'rigorous scientific gravity was combined with a childlike, cheerful nature and the kindness of a wise and always helpful, truly good man' (Marx 1919: 130 [my translation]). After the expedition, he studied science under Chun in Leipzig, but on his father's death he left to run the family printers. He printed the plates in the extensive series of scientific publications resulting from the expedition (Chun 1908), where the lithographic printing technique creates an 'amazing and lifelike iridescent colouring of the fish, and manages to turn somewhat ugly creatures into almost beautiful ones!' (Cambridge University Department of Zoology 2011). Fig. 2 is an example of how Winter could effectively merge analytic/scientific and aesthetic depiction.

Winter's ways of seeing were circumscribed by youth and experience previously restricted to the Frankfurt-amMain locality, but he had that 'childlike, cheerful nature', was passionate about the natural world and was enjoying the adventure of a lifetime.

An article written by Winter in 1900 (Winter 1900) is largely about scientific observations of the icebergs. This academic focus is also predominant in the photographs and watercolours Winter created. Depicting icebergs of various types, they are representational rather than artistic, although pleasing to the eye. Winter first photographed the scene in the image in Fig. 3 from a small boat put out on a relatively calm sea (Chun 1903: 216), then made the watercolour shown here, in pastel tints (Chun 1903: following 220). The image, composed in horizontals, documents the event, contrasting the wonder and immensity of nature with the utilitarian and plain-looking little Valdivia. It highlights the enormity of the iceberg compared to the ship, allowing the viewer to appreciate the danger, and to admire the daring and enterprise of the expedition. However, Winter's gaze here was predominantly informed by rational scientific purpose and interest, and the image 


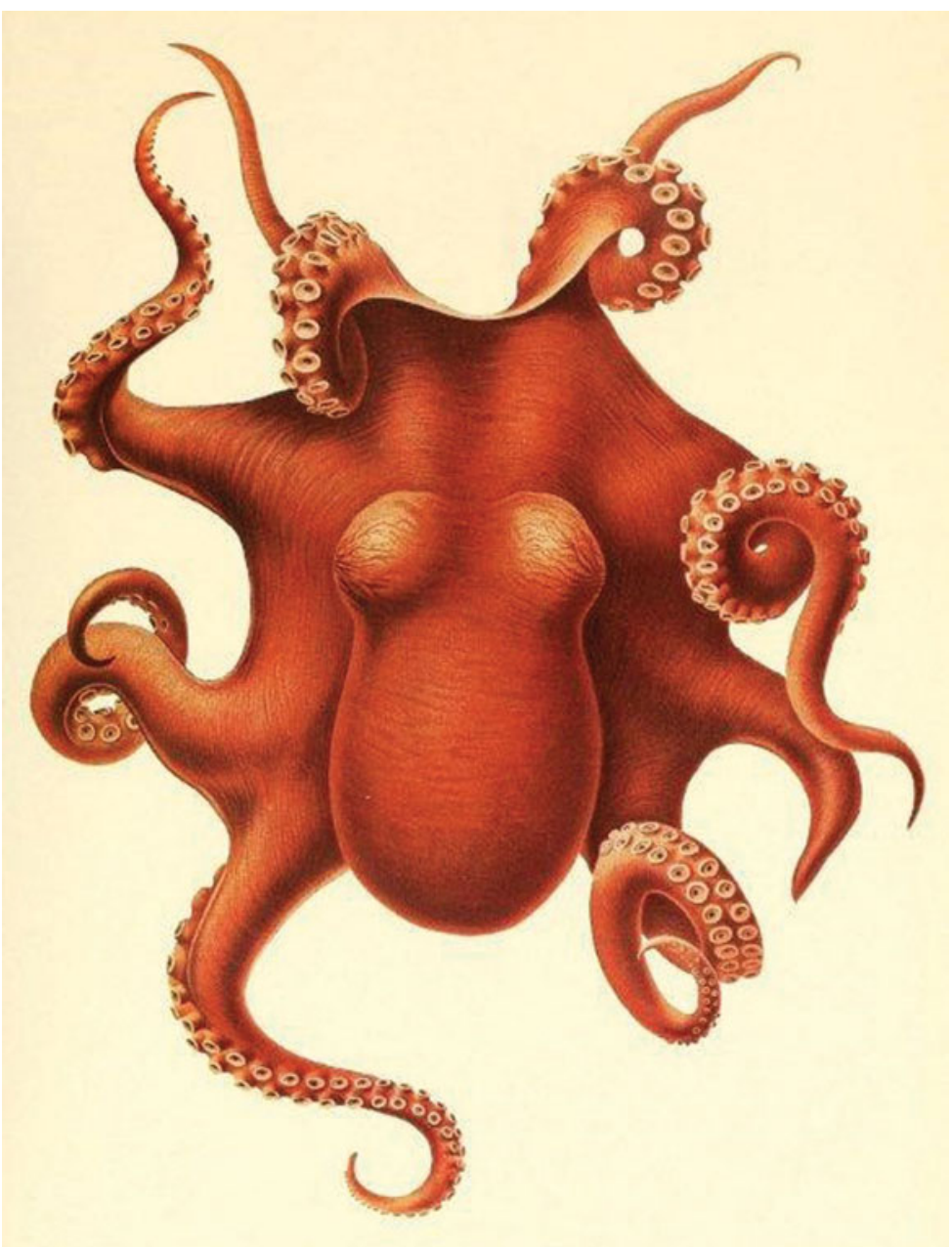

Fig. 2. Polypus levis Hoyle, from Kerguelen. (artwork: Winter) (Source: Chun 1915, p. 201)

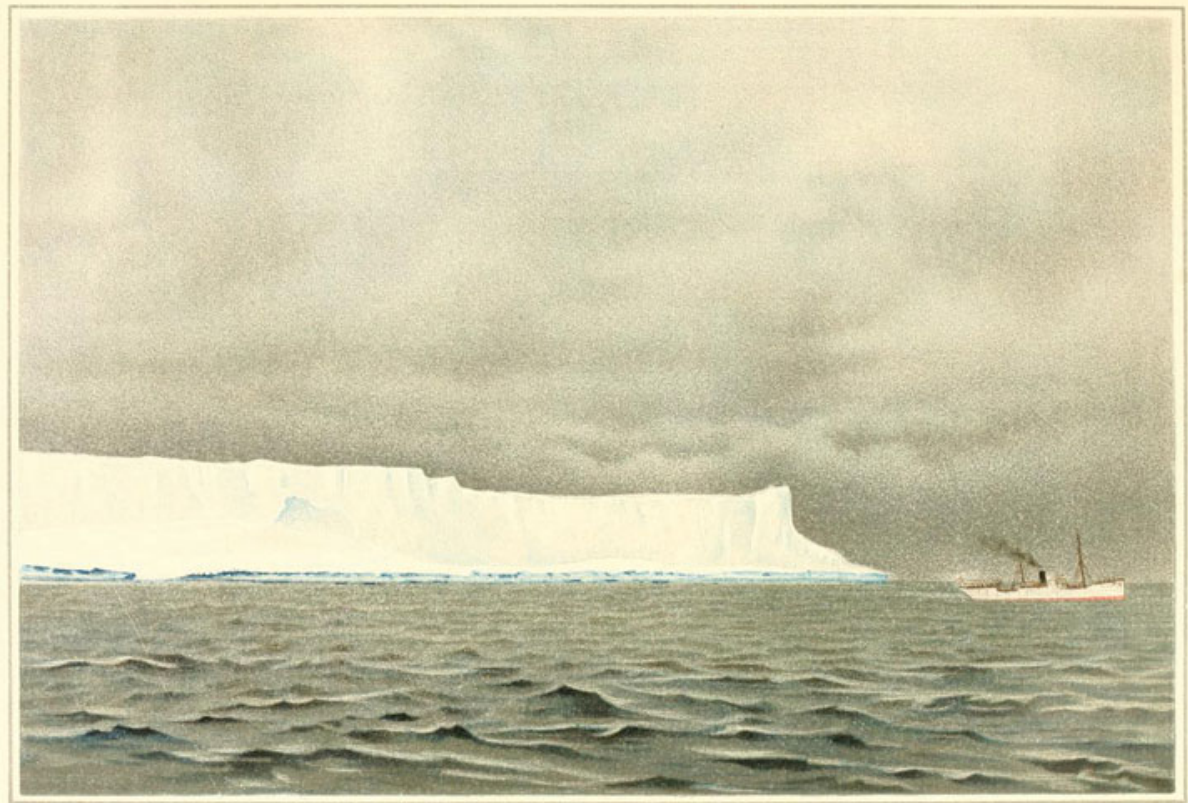

Fig. 3. Iceberg seen on December 7, 1898. (Watercolour: F. Winter.) In: C. Chun 1903: 220. 
lacks the aesthetic appeal of his illustration of a specimen in Fig. 2.

There is very little colour in the sombre image: a glowering sky and a grey sea, some blue shading on the iceberg indicating the weathering features which Winter went on to discuss in the 1900 article cited above, and a blue line where the iceberg floats on a grey sea. There is a touch of red on the Valdivia. The ship looks plucky, but commonplace. But the fact that he took the trouble to represent the iceberg and the ship together from a distance is significant: Valdivia's month in the subAntarctic ice was for Germany a significant resumption of the polar exploration that had begun with expeditions to the North Pole. Imperial Germany on the threshold of the twentieth century hoped for status in science and exploration as a result of the Deep Sea Expedition, a 'nationalistic attempt to keep up with the successful deepsea expeditions in particular by the British ... Challenger expedition' (Glaubrecht and others 2005: 152). Kaiser Wilhelm II took an interest in it, and the Secretary of the Interior and other state dignitaries attended the launch. Chun recognised the benefits of empire. 'Before the establishment of the German Empire,' he wrote, 'one could not have imagined such a scientific expedition equipped by Germany' (Chun 1903: 13, my translation). The artwork framing the first page of Chapter Two of his narrative, 'Equipment', featured the imperial flag dominant above an arrangement of specimen collection nets and scientific equipment (Chun 1903: 12). The photograph of the crowd at departure (Chun 1903: 13) also shows imperial flags, conceptual representations of the still relatively new group membership. The Reich appears to have been exploiting the expedition's propaganda value (Schmidt-Ott 1952).

Though scientific interests dominated for the expeditioners, for the nation and the funders, its images would have significance beyond the scientific; they contributed to Germans' sense of who they were in a changing world.

\section{German South Polar Expedition: Emil Philippi}

The German South Polar Expedition (1901-1903) was led by Erich von Drygalski, professor of geography and geophysics at Berlin University, an Arctic investigator and glaciologist. His plan for the expedition profited from the fact that it also coincided with political impetus to seek national promotion (Lüdecke 1995), and the German government funded the expedition with, according to W.S. Bruce, the naturalist, polar scientist and oceanographer who would lead the Scottish National Antarctic Expedition (1902-1904), 'considerably more than twice the amount voted by the British Government for the [contemporaneous] British expedition' (Bruce 1901: 461).

Like the Deep Sea Expedition, however, the South Polar Expedition itself saw its purpose as mainly scientific: Drygalski's plan was from inception all about scientific inquiry into Antarctic geography, geomagnetism, meteorology, hydrography, geology and geomorphology.

The expedition's official photographer was Dr Emil Philippi, a geologist and chemist, who, like most of those on the expedition, had no experience at high latitudes. A young product of the German university system, Philippi (1871-1910) already had a promising scientific reputation. He developed a strong work relationship with Drygalski through their common passion for glaciology. His 'ways of seeing' in Antarctica were shaped by his science background.

The image in Fig. 4 is an aerial view of the expedition ship Gauss in the Davis Sea ice, taken from a hydrogen balloon provided by the Royal Prussian Airship Department, technology provided to the expedition with the purpose of measuring air temperature, pressure and humidity at various elevations, for researching destinations for sledging journeys and providing information about a probable best eventual escape route from the ice. Secured by a cable $1200 \mathrm{~m}$ long, $60 \mathrm{~m}$ west of the icebound ship, the balloon and Drygalski ascended to $480 \mathrm{~m}$ on a sunny, still day in March 1902. In the afternoon there were two more ascents. Philippi ascended to $300 \mathrm{~m}$ (Stehr 1903), where he 'managed to take some fine photographs' (Drygalski 1989: 158).

Philippi took the photograph in Fig. 4 to document the balloon ascents, and as such it fits well with the expedition's scientific/analytical focus. But a particular angle can give a documentary photograph an enhanced level of meaning. Gauss was intentionally icebound, an audacious plan at the time (Murphy 2002). Like Winter's image of the ship with the iceberg, Philippi's photograph of Gauss in the ice depicts the exciting achievement for the audience at home. But aerial vision gives the photograph a further dimension. It provides a way of conceptualising the world, here indicating a continuation of the western tradition of dominance through technology-based power. An aerial view has connotations of superiority and serene transcendence (Dorrian and Pousin 2012). But the grip of the ice, the power of nature, is also striking. Philippi's photograph conveys a paradox: the explorers are at once dominant and insignificant. It is the "paradox of encounter - between an indifferent ice and humans intent on colonising the uninhabitable' identified in the Heroic Age aesthetic by Glasberg (2012: 92).

The concurrent British National Antarctic Expedition (1901-1904) under R.F. Scott also took balloon photographs, and significantly achieved the earliest extensive exploration on land in Antarctica, with a sledge party reaching farthest south at $88^{\circ} 28^{\prime}$. A perception of comparative failure that met the German expedition on its return home was refuted in vain by Drygalski. The Kaiser's response was frosty:

A higher latitude reached by the expedition would have been much more useful in the geopolitical context (Lüdecke 1995).

However, Drygalski's narrative of the expedition, which appeared quickly (Drygalski 1904), sold very 


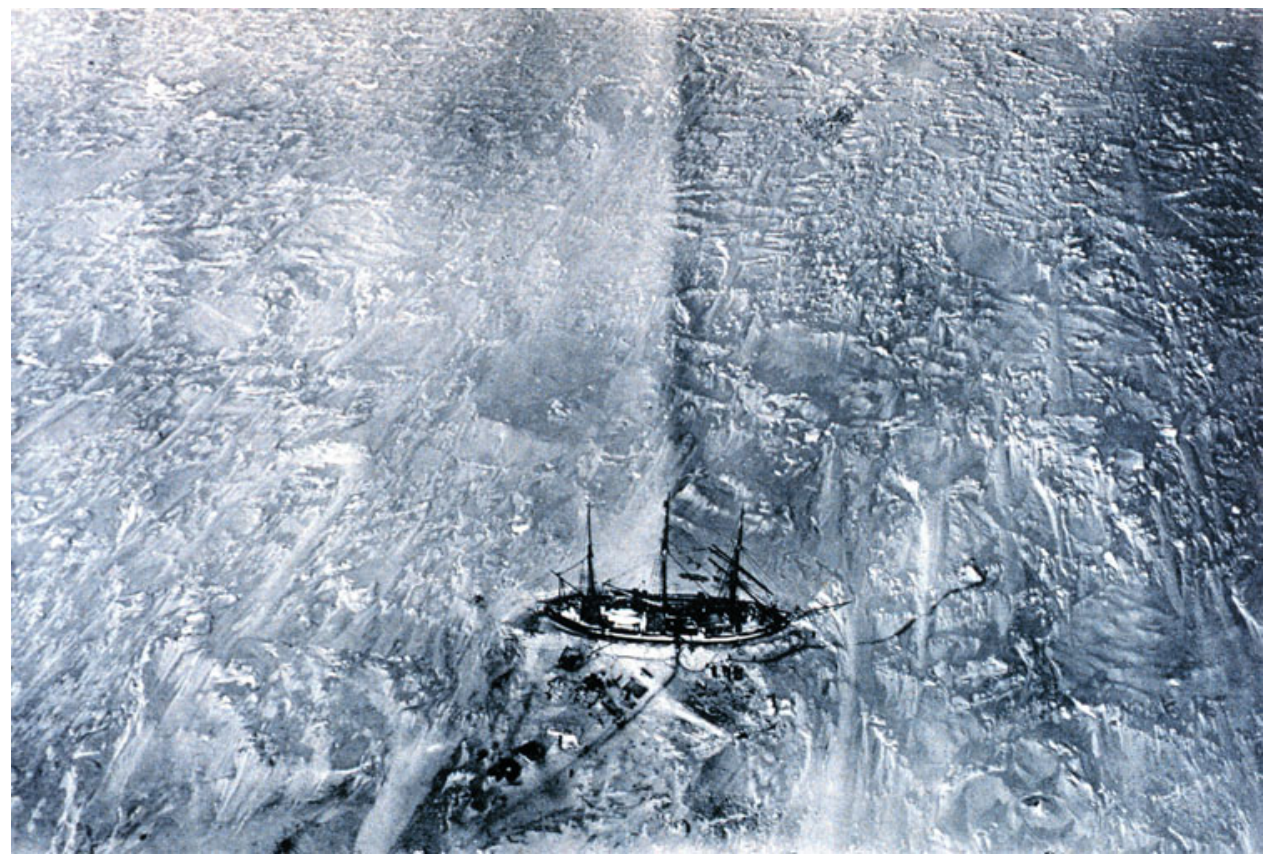

Fig. 4. Aerial view of the Gauss in the ice, 1902 (Photo: E. Philippi) (In E. von Drygalski 1905-31, Bd. 3, Teil 1, Plate 1: 337)

well, due partly to its comprehensive illustrations (Müller 2009). It marked an important stage in the history of polar photography: 'photography documented almost every step on the pristine Antarctic expanses' (Müller 2009: 237 [my translation]). The voluminous scientific results published during the decades after the expedition (Drygalski 1905-1931), all with 'on behalf of the Reich Office of the Interior' in the title, were described by the Royal Geographical Society, London, as 'finely printed and generously illustrated' ('Gauss Antarctic Reports: Review' 1932: 507). Drygalski lectured to good crowds all over Germany for a decade after the expedition (Murphy 2002), presumably using photographs.

Expedition photographs were also among the Antarctic artefacts at the Exhibition of the German Empire at the Louisiana Purchase Exposition (or World's Fair) in St Louis, Missouri, in 1904 (Official Catalogue of Exhibitors 1904), and were part of a diorama at the Colonial Exposition at Marseille in 1906 (Lüdecke 1995). Antarctic dioramas installed in the Berlin Institute for Oceanography in 1906 and the Berlin Museum of National History in 1912 (Murphy 2002) would have been based on the photographs.

\section{Crushed by ice: Swedish South Polar Expedition}

The Swedish South Polar Expedition was beset by major problems. A shore party of six men, headed by Otto Nordenskjöld, stayed on Snow Hill Island off the Trinity Peninsula area of the Antarctic Peninsula through 1902 and 1903, mapping parts of the coast. At the end of the 1902 winter their ship, Antarctic, could not reach them as planned, and three men were landed at Hope Bay in an attempt to reach them by going overland. Conditions forced those men to winter there in 1903 in an improvised rough stone hut with minimal supplies. The Antarctic was crushed in the pack ice and foundered on 13 February 1903, its crew wintering on Paulet Island. All three parties were rescued by an Argentine naval vessel in November 1903. The expedition nevertheless managed to conduct a comprehensive scientific program, with results since claimed to be 'greater than those of any other up to that time' (Fuchs 1979: iv).

The primary narrative accessible to English speakers is Antarctica or two years amongst the ice of the South Pole, by Nordenskjöld, second-in-command and geologist J.G. Andersson, botanist Carl Skottsberg and Captain Carl Larsen, which includes a wide variety of photographs taken by various expedition members. Many of them have been retouched with a pen, suggesting that the photographers had difficulty with exposures. They rarely mention photography in the text. It was part of their recording of activities, important - 'every photographic apparatus was at work' (Nordenskjöld and Andersson 1905: 34) - but routine.

\section{Captain Carl Larsen}

Carl Anton Larsen (1860-1924) was a Norwegian sea captain and whaler with extensive experience in Arctic and Antarctic exploration. His writings, for example, The Voyage of the Jason to the Antarctic Regions (Larsen 1894), reveal an interest in the natural sciences, and he discovered the first fossils found in south polar regions during his voyages in 1892 and 1893-1894 (Nordenskjöld and Andersson 1905). He captained the steamship Antarctic for the Swedish expedition. Larsen had more sense of the cultural imaginary of ice than did other illustrators in 


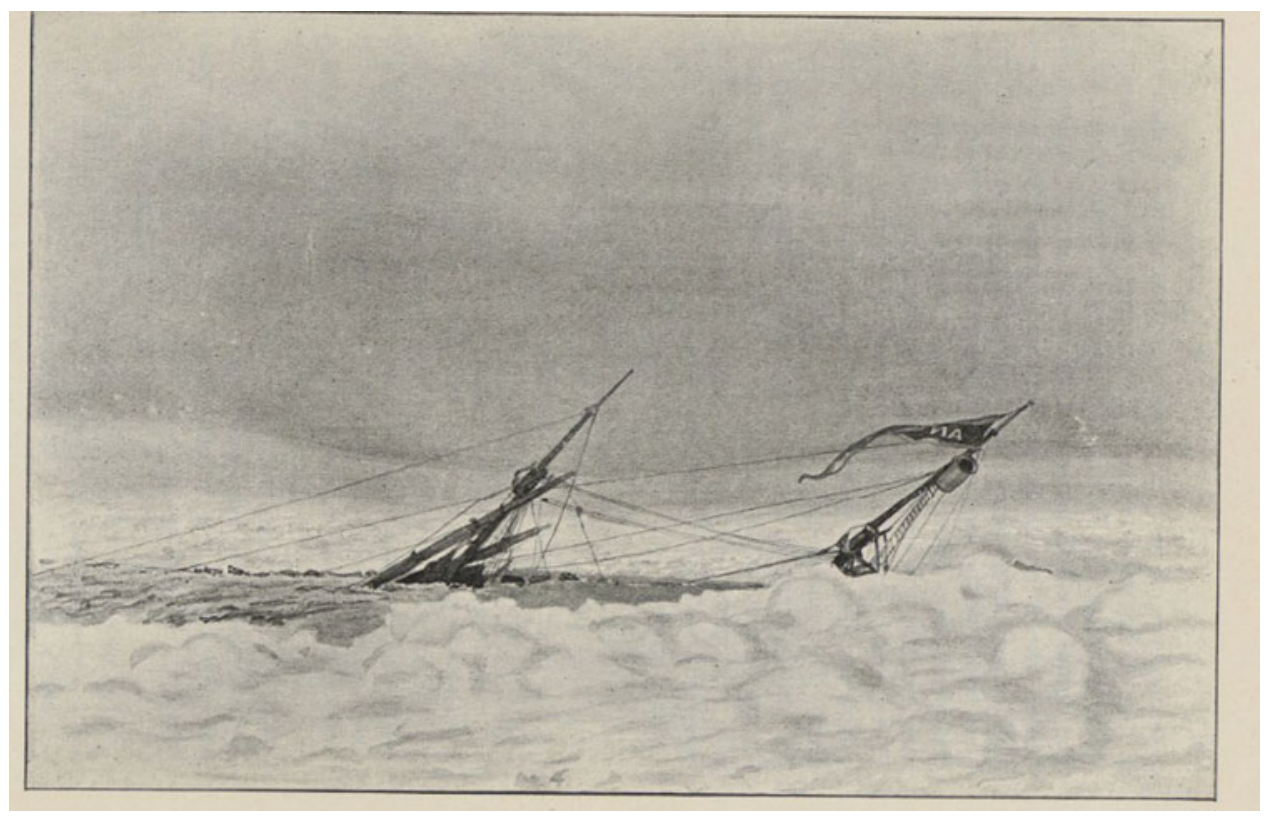

Fig. 5. The loss of the Antarctic (Photo: C.A. Larsen)

In: O. Nordenskjöld and J.G. Andersson 1905: 535.

this paper, but this was reinforced by recent and practical experience sailing in icy regions.

Larsen took serial photographs of the crushing of the Antarctic on 12 February 1903. Fig. 5 shows its final agony.

The botanist Skottsberg wrote:

We have now examined the stern of the vessel and have learned the full extent of our misfortunes. One-third of the vessel's keel has disappeared ... A hole has been made that no human skill here can close ... I go up on the bridge. Larsen is there. One can see suspense painted in his features - do you know how it feels for a skipper to lose his craft? ... Slowly but surely rises the water ... Now the water is up to the rail, and, with a rattle, the sea and bits of ice rush in over her deck. That sound I can never forget, no matter how long I may live ... She is gone! (Nordenskjöld and Andersson 1905: 530-536)

Ways of seeing are linked with identity (Berger 1972), which is constructed within various fields of relations built around shifting perspectives on what it means to be recognised as a certain kind of person (Davies and Harre 1990). One perspective is an institutional one, whereby an individual holds the rights and responsibilities that go with a position or calling (Gee 2001). Larsen's emotions would have been to the fore as he meticulously recorded the stages of the event, every sea captain's nightmare. The fate of expeditioners in three inhospitable and isolated locations had depended on his ship. Antarctic also had the affection of crew, captain and many others, having served several Swedish expeditions to Greenland and Spitzbergen before this one. In 1944 Johan Gunnar Andersson published a commemorative book, Antarctic: stolt har hon levat stolt skall hon dö
(Antarctic: proud she lived proud she shall die). Fig. 5 is an image viewed through an emotional lens of anxiety and grief.

\section{Fairyland ice: French Antarctic Expedition}

Dr Jean-Baptiste Charcot (1867-1936) led two expeditions to the Antarctic. Both had significant scientific and geographical results, which later appeared in a series of publications by the Institute of France. However, Charcot's motivation came above all from a lifelong love of the sea and a yearning for adventure (Oulié 1938). His first expedition of 1903-1905 to the west coast of the Antarctic Peninsula was privately funded, but with some government support in the form of two naval officers' salaries (Lewander 2003), and Charcot persuaded the authorities to recognise it as the official 'Expédition Antarctique Française' under the patronage of the President of the Republic. It was thus represented from the start as a national expedition.

\section{Paul Pléneau}

Engineer Paul Pléneau (1869-1949) did much of the photography, also writing a brief account of the photographic work (Charcot 1906). Nothing is known about how he might have envisioned Antarctica before going there, but, like Charcot, he had an early yearning for the sea and adventure. Instead he had done his military service, then studied engineering in Paris, later moving back to his home region of Bordeaux to work as an engineer of agricultural machinery (Fouquet 2012). By 1902 he was again in Paris, managing an engineering company specialising in steam engines and pumps, and enjoying theatre life. But he had seen an article about Charcot's plan of that time 
to go to the North Pole, and to this he signed on as engineer:

This man was leaving on the kind of adventure I yearned for. I could not let a chance like this pass (quoted in Fouquet 2012: 47 [my translation]).

The destination was changed to Antarctica, the intention initially being to search for the lost Nordenskjöld expedition, and Pléneau sent Charcot an oft quoted telegram:

Where you like. When you like. For as long as you like (quoted in Fouquet 2012: 47 [my translation]).

Pléneau was thus a man working in an applied science field and yearning for adventure. 'Pléneau', wrote Charcot, 'is the man you want for these kinds of adventures, strong and sturdy above the average, with unfailing good humour and wit' (1906: 236 [my translation]). Another comrade described him as 'a man who didn't know the meaning of fear' (quoted in Lecoq 1936: 4 [my translation]).

Nevertheless, Pléneau's photographs demonstrate an awareness of fearful situations and human emotions in Antarctica. He wrote that he looked forward to the advent of colour photography for its greater realism:

Its wonderful depiction of this fairyland of ice will be a revelation. The eternal black and white people usually imagine will be replaced by a lavish spectacle illuminated by thousands of lights shining in the sky (Pléneau 1906: 460 [my translation]).

Clearly, his interest was more captivated by the emotional/aesthetic aspect of Antarctica than by the scientific/analytical. His 'fairyland of ice' echoes the reflections of other western explorers. This was not the fairyland of children's stories, more the 'other world' of folklore. It was linked to the yearning for adventure: 'the call of the unknown - the longing for the land of Beyond, the divine force deeply rooted in the soul of man ...' (Nansen 1927: 20 quoted in Hastrup 2007: 791), and was also an aspect of the 'fascinating interaction between art and science, fact and fantasy' (Andrews 2007: 66) in representations of polar exploration. It had been a recurring idea in Arctic narratives, with the language of the supernatural used along with that of the sublime (McCorristine 2010). Fridtjof Nansen's seminal narrative of his 1893-95 Arctic expedition had included expressions such as: 'a fairyland - a land of dreams' (Nansen 1897: 101) and 'a fairy tale from another world' (577). Descriptions like these and others flowed into the shared cultural imaginary which inevitably influenced Antarctic explorers' interactions with the scenes they encountered there (Wråkberg 2007). Charcot used the term 'féerique' ('fairy', 'magical' or 'enchanting') a number of times in his narrative. The metaphor, related to romanticism, evokes the powerful sense of enthrallment often experienced by polar explorers.

Pléneau's remarkable photograph in Fig. 6 evokes the quality of fable. The ship appears as if being transported on the ice to another world.
The photograph was taken on 25 February 1904, near Wandel Island, where the expedition wintered. Français was a relatively small schooner, and its position seems highly precarious. The crew knew that Nordenskjöld's Antarctic had been caught in the ice a year before. It is a photograph that excitingly documents the situation for those at home, but infused as it is with apprehension communicated by the unique view, it also draws on discourses of national pride, heroism and adventure.

Pléneau's photograph in Fig. 7 evokes again the idea of Antarctica as 'a gateway to previously unimagined spaces' (Leane 2004: 153). The scene is glowing but hazy, the iceberg arch a mystic portal approached by the explorers' whaleboat: the 'fairyland of ice', enticing, nebulous, dangerous, drawing them in - the dangers of Antarctic exploration given metaphorical resonance in a photograph.

\section{Ice floes: Japanese Antarctic Expedition}

The Japanese had no history of polar exploration, and the Japanese Antarctic Expedition (1910-12) was the sole initiative of Shirase Nobu (1861-1946), a former army lieutenant, who unsuccessfully petitioned support from his government with reference to Japan's need to establish a modern, scientific image in the world (Stevenson 2010). The expedition was eventually supported financially by a prominent nobleman. Shirase and his expeditioners sought to provide documentation that would validate the worth of their exploration in terms of national pride as well as science.

\section{Nomura Naokichi}

Like other Heroic Era illustrators, the expedition depicted its experience amid icebergs. Nomura Naokichi, captain of the expedition ship Kainan Maru, whose navigational skills were complemented by proficient draughtsmanship and skills at painting and drawing (Shibata and Dagnell 2012), had no polar experience (Stevenson 2010: 128). He had previously sailed north of Japan to the Kamchatka region, where he may have seen some sea ice, but the icebergs of Antarctica would have been entirely new to him.

The Japanese had seen some other expeditions' photographs. Stevenson (2010: 128) states that Nomura had sought information on Antarctic navigation in various Tokyo libraries, which may have included some illustrations. As part of fundraising, Shirase had participated in lantern slide lectures where images of Scott's and Shackleton's expeditions were shown. Shirase had met a polar-enthusiast journalist who had a copy of Shackleton's 1909 Nimrod narrative, profusely illustrated, and on the way south, in Wellington, he acquired a copy of his own (Stevenson 2010). Thus the expedition came to share, to a limited extent, in the western cultural imaginary of the Antarctic ice. But the Japanese continually appealed to images of home to describe what they saw and experienced on the ice. Looking out over the Bay of Whales in 


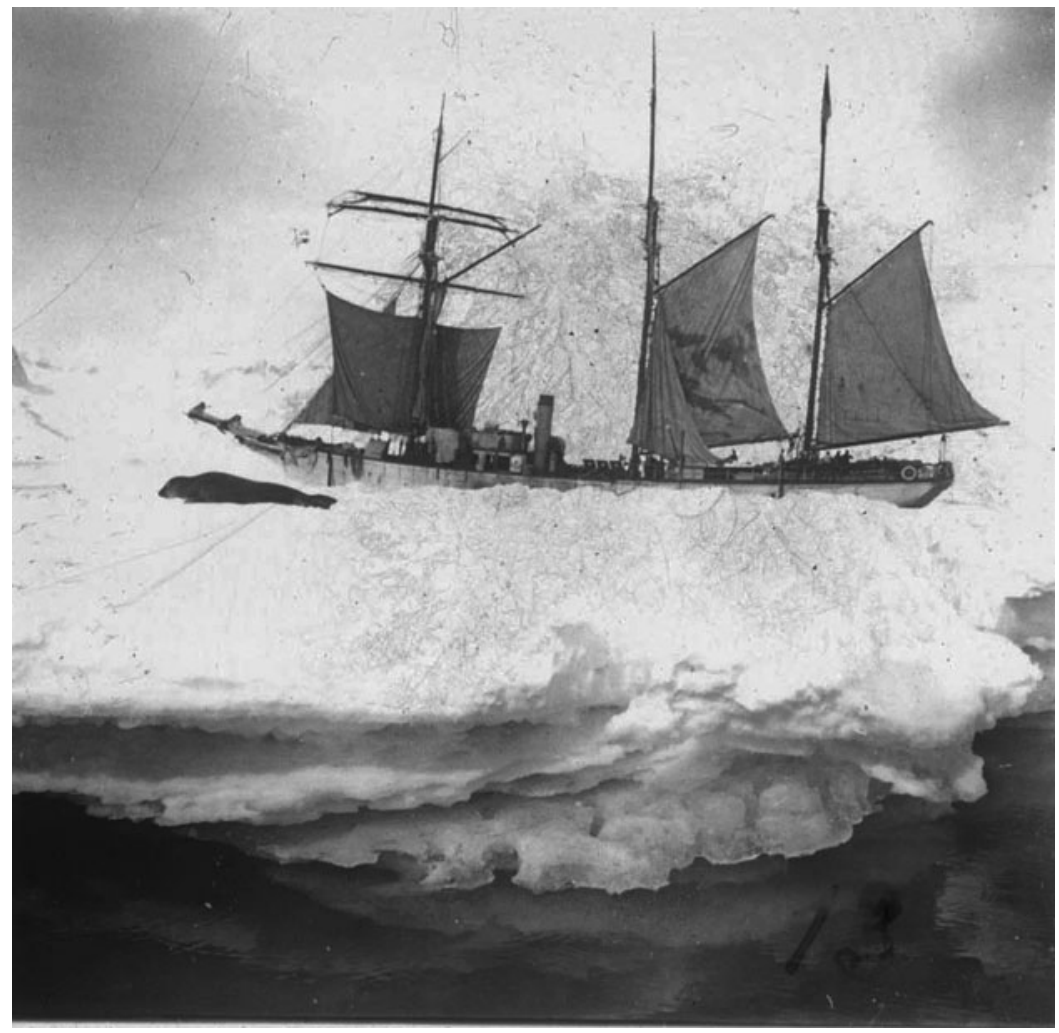

Fig. 6. Français in the pack ice around Wandel Island, 1904 (Photo: P. Pléneau)

Source: Glass plate negative, Univ. Bordeaux, Musée d'ethnographie.

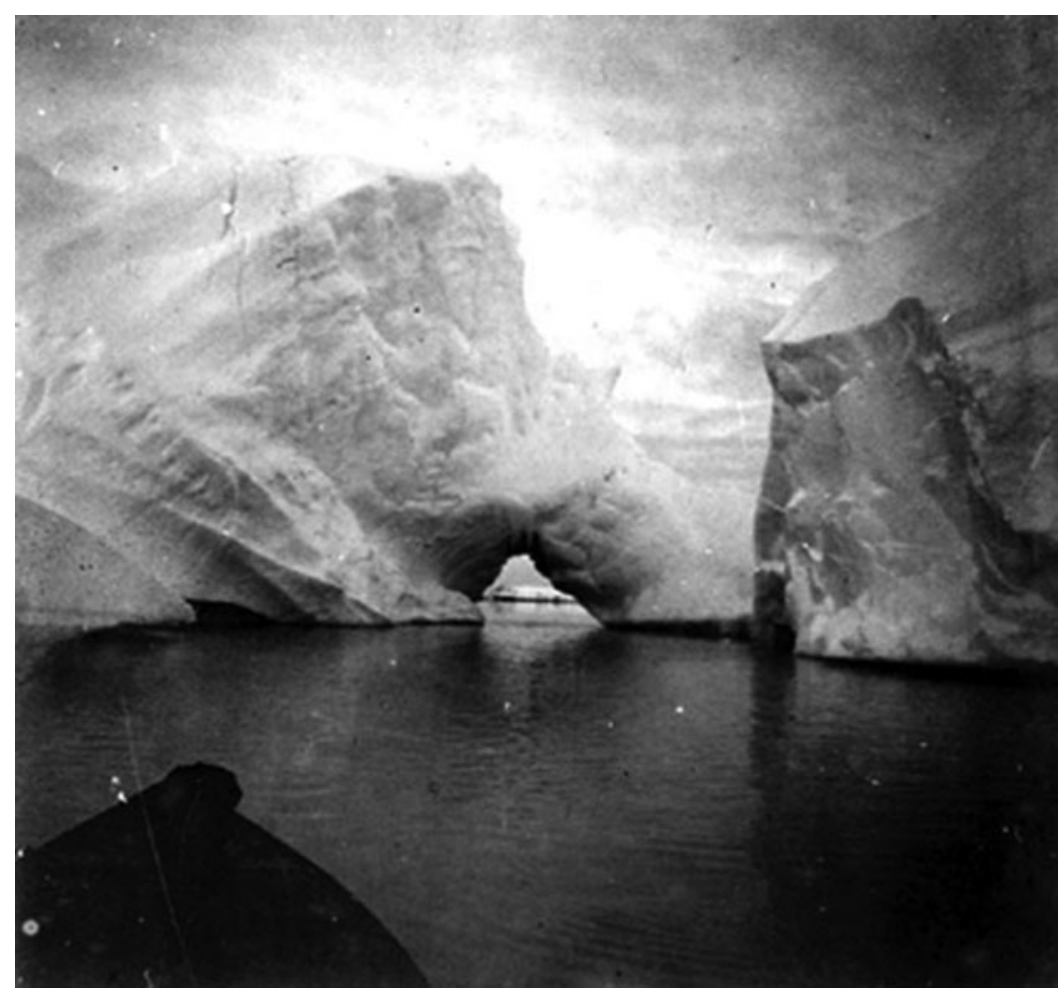

Fig. 7. $20 \mathrm{~m}$ high arch in an iceberg around $50 \mathrm{~m}$ high (Photo: P. Pléneau) (Source: Glass plate negative, Univ. Bordeaux, Musée d'ethnographie) 


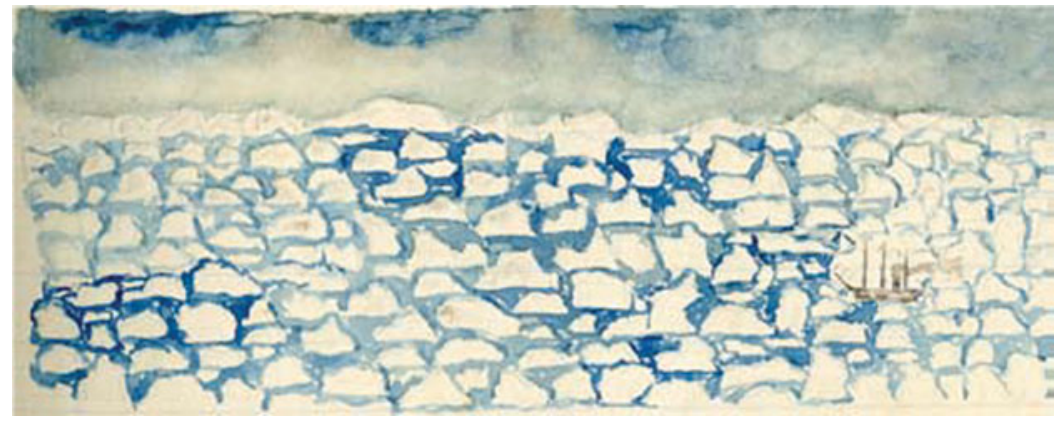

Fig. 8. Kainan Maru struggles through icy seas (Watercolour: Capt. Nomura) Source: H. Shibata 2012. Courtesy of the Hakui Historical Museum, Ishikawa-ken, Japan.

Antarctica was 'a sumie world painted in Indian ink on white paper' (Shirase and the Japanese Antarctic Expedition Supporters Association 2011: 139). One of the young sailors, Miyake Yukihiko, produced some of these ink washes. However, a watercolour sketch from Captain Nomura's diary uses blue and white to show the Kainan Maru in the pack ice (Fig. 8).

Shirase wrote of,

the sublime grandeur of this white fleet sailing to the attack in such graceful strength. As the great chunks of ice ... collided against the sides of the ship the noise they made was rather like the booming of artillery (Shirase and the Japanese Antarctic Expedition Supporters Association 2011: 98).

The war imagery came naturally to the expedition members, most of whom, including Nomura, had served in the Russo-Japanese War. His watercolour depicts the tiny ship forcing a way through the attacking fleet of ice floes. But the conceptualisation - the ship in a choked sea of ice - has a delicate translucent quality that gives it an other world dimension. The white of the ice is emphasised by the lapis lazuli blue of the sea. A leaden fog threatens from the upper part of the scene. The situation is highly dangerous, with the sea seeming 'like the realm of some evil spirit' (Shirase and the Japanese Antarctic Expedition Supporters Association 2011: 102), and Nomura's image suggests the psychological states of the expeditioners. In the words of Hilary Shibata:

This image of Kainan Maru struggling through the pack is an image of emotion, of how it felt to be in that tiny ship besieged by the ice floes (Shibata 2012: 86).

\section{Conclusion}

All Heroic Era expeditions produced images of their ships in the Antarctic ice, evidence of their achievement on behalf of their country, with a strong promotional aspect with a view to raising funds for new expeditions or for publications. Some images have a special power to suggest psychological and emotional aspects of the expeditioners. The images from lesser known expeditioners examined here draw on the prevailing Heroic Era discourses of scientific endeavour and national pride, and also evoke the awe and wonder of the Antarctic world, and a sense of myth. They are a vivid record of their creators' ways of seeing, and of their ways of resolving the tension between emotive/aesthetic and analytic/scientific motifs in documenting Antarctic exploration.

\section{Acknowledgements}

My thanks to Professor Aant Elzinga, who marked my Master's thesis (2013), and whose remark on the tension between emotive/aesthetic and analytic/scientific motifs inspired this article.

\section{References}

Amundsen, R. 1912. The South Pole: an account of the Norwegian Antarctic Expedition in the "Fram", 1910-1912. London: John Murray.

Andersson, J.G. 1944. Antarctic: stolt har hon levat, stolt skall hon do"[Antarctic: proud she lived proud she shall die]. Stockholm: Saxon and Lindstrom.

Andrews, L. 2007. Antarctic eye: the visual journey. Mount Rumney, Tasmania: Studio One.

Arçtowski, H. 1901. Exploration of Antarctic lands. The Geographical Journal 17: 150-180.

Arçtowski, H. 1908. Océanographie: les glaces: glace de mer et banquises. In: Expédition antarctique belge: résultats du voyage du S.Y. Belgica en 1897-1898-1899. Rapports scientifiques. Anvers: J-E Buschmann.

Arnold, H.J.P. 1971. Photographer of the world: the biography of Herbert Ponting. Cranbury, NJ: Associated University Presses.

Barr, S. 1997. Expedition photography in polar areas. Photoresearcher 6: 47-54.

Barthes, R. 1977. Elements of semiology. New York, NY: Hill and Wang.

Barwell, C. 2007. Frozen memories: unthawing Scott of the Antarctic in cultural memory. Visual Communication 6: 345357.

Berger, J. 1972. Ways of seeing. Harmondsworth: Penguin.

Bruce, W.S. 1901. The German South Polar Expedition. Scottish Geographical Magazine 17: 461-467.

Cambridge University Department of Zoology. 2011. Special collections, current display, Wissenschaftliche Ergebnisse der deutschen Tiefsee-Expedition auf dem Dampfer "Valdivia" 1898-1899, im Auftrage des Reichsamtes des Innern, herausgegeben von Carl Chun. Fünfzehnter Band. Die Tiefsee-Fische, bearbeitet von August Brauer. 1. Systemat- 
ischer Teil. Jena: Gustav Fischer: 1908. URL: http://www.zoo. cam.ac.uk/department/library/special-collections, (accessed 30 December 2016.)

Charcot, J.-B. 1906. Le "Français" au Pôle Sud: journal de L'expédition Antarctique Française, 1903-1905. Paris: Flammarion.

Chun, C. 1903. Aus den tiefen des weltmeeres: schilderungen von der Deutschen Tiefsee-Expedition (2nd edition). Jena: Gustav Fischer.

Chun, C. 1908. Wissenschaftliche ergebnisse der deutschen Tiefsee-Expedition auf dem dampfer 'Valdivia' 1898-1899. Jena: Gustav Fischer.

David, R.G. 2000. The Arctic in the British imagination, 18181914. Manchester: Manchester University Press.

Davies, B. and R. Harre 1990. Positioning: the discursive production of selves. The Journal for the Theory of Social Behavior 20: 43-63.

Dawson, G. 1994. Soldier heroes: British adventure, empire, and the imagining of masculinities. Abingdon: Routledge.

Dorrian, M. and F. Pousin 2012. Seeing from above: the aerial view in visual culture. London: IB Tauris.

Drygalski, E., von. 1904. Zum kontinent des eisigen südens: Deutsche Südpolarexpedition, fahrten und forschungen des 'Gauss' 1901-1903. Berlin: Reimer.

Drygalski, E., von. 1989. The southern ice-continent: the German South Polar Expedition aboard the Gauss 19011903, translated by M.M. Raraty. Bluntisham: Bluntisham Books.

Drygalski, E., von. 1905-1931. Deutsche Südpolar-Expedition 1901-1903. Berlin: Reimer.

Ennis, H. 2002. Man with a camera: Frank Hurley overseas. Canberra: National Library of Australia.

Fouquet, A.L. 2012. Paul Pléneau (1869-1949). Centraliens 618 : 46-48.

Fuchs, V. 1979. Foreword. In: J. Boddington. Antarctic photographs 1910-16: Herbert Ponting and Frank Hurley. South Melbourne: Macmillan.

Gauss Antarctic Reports: Review. 1932. The Geographical Journal, 79, (6): 506-508

Gee, J.P. 2001. Identity as an analytic lens for research in education. Review of Research in Education 25: 99-125.

Glasberg, E. 2012. Antarctica as cultural critique: the gendered politics of scientific exploration and climate change. New York, NY: Palgrave MacMillan.

Glaubrecht, M., L. Maitas and L. von Salvini-Plawen. 2005. Aplacophoran Mollusca in the Natural History Museum Berlin. An annotated catalogue of Thiele's type specimens, with a brief review of "Aplacophora" classification. Mitteilungen aus dem Museum für Naturkunde in Berlin, Zoologie series 812 145-166.

Hastrup, K. 2007. Ultima thule: anthropology and the call of the unknown. The Journal of the Royal Anthropological Institute 13: 789-804.

Hodge, G.P. 2003. Introduction. In: Hodges, E.R.S. (editor). The guild handbook of scientific illustration (2nd edition). Hoboken, NJ: John Wiley and Sons: ix-xiv.

Lane, H. and L. Martin. 2006. The Antarctic photographs of Herbert Ponting: iconic images from Scott's British Antarctic Expedition 1910-1913. London: Foreign and Commonwealth Office.

Larsen, C.A. 1894. The voyage of the Jason to the Antarctic regions. The Geographical Journal 4: 333-344.

Leane, E. 2004. Romancing the pole: a survey of nineteenthcentury Antarctic utopias. Australian Cultural History 23: 161-184.
Lecoq, J. 1936. Le docteur Jean Charcot, explorateur polaire: Charcot et ses hommes. Le Petit journal illustré 27 September: 4.

Lewander, L. 2003. The Swedish relief expedition to Antarctica, 1903-04. Polar Record 39: 97-110.

Lüdecke, C. 1995. Die deutsche polarforschung seit der jahrhundertwende und der einfluß Erich von Drygalskis. Dissertation, Berichte zur Polarforschung, 158 (XIV). URL: http://epic.awi. de/2005/, (accessed 5 June 2016).

Lutz, C. and J. Collins. 2003. The photograph as an intersection of gazes: the example of National Geographic. In: Wells, L. (editor). The photography reader. Abingdon: Routledge: 164179.

Machowski, J. 1998a. Contribution of H. Arçtowski and A.B. Dobrowolski to the Antarctic expedition of Belgica (18971899). Polish Polar Research 19: 15-30.

Machowski, J. 1998b. Henryk Arçtowski. Polish Polar Research 19: 7-10.

Marx, E. 1919. Fritz Winter, 21 Juni 1878 - 8 Juli 1917. Frankfurt-am-Main: Senckenberg Nature Research Society: 126-131. URL: http://www.biodiversitylibrary.org/ia/ naturundmuseum49senc\#page/149/mode/1up, (accessed 3 June 2016).

McCorristine, S. 2010. The supernatural Arctic: an exploration. Nordic Journal of English Studies 9: 47-70.

McGregor, A. 2004. Frank Hurley: a photographer's life. Camberwell, VIC: Viking.

Millar, P. 2015. Frederick A. Cook: the role of photography in the making of his polar explorer-hero image. Polar Record 51: 432-443.

Müller, D. 2009. Fotografie und Südpolforschung um 1900. In: Hüppauf, B. and P. Weingart. Frosch und Frankenstein: bilder als medium der popularisierung von wissenschaft. Bielefeld: Transcript: 233-254.

Murphy, D.T. 2002. German exploration of the polar world: a history, 1870-1940. Lincoln, NE: University of Nebraska Press.

Nansen, F. 1897. Farthest north: being the record of a voyage of exploration of the ship 'Fram' 1893-96 and of a fifteen months' sleigh journey by Dr. Nansen and Lieut. Johansen. New York, NY: Harper and Brothers.

Newhall, B. 1972. The history of photography from 1839 to the present day. London: Secker and Warburg.

Nordenskjöld, O. and J.G. Andersson. 1905. Antarctica, or two years amongst the ice of the South Pole. London: Hurst and Blackett.

Official Catalogue of Exhibitors. 1904. 'Universal Exposition St Louis, USA,' The Official Catalogue Company, St Louis, viewed 21 May 2016, http://www.archive.org/details/ officialcatalogu00louiâ

Oulié, M. 1938. Charcot of the Antarctic. London: John Murray.

Pléneau, P. 1906. Note sur la photographie. In: Charcot, J.-B. Le "Français" au Pole Sud: journal de L'expedition Antarctique Française, 1903-1905. Paris: Flammarion: Appendix VII: 459-462.

Pyne, S. 1986. Heart of whiteness: the exploration of Antarctica. Environmental Review 10: 231-246.

Raraty, M.M. 1998. Translator's introduction. In: de Gerlache de Gomery, A. Fifteen months in the Antarctic. Norfolk: The Erskine Press and Bluntisham Books: xi-xxii.

Riffenburgh, B. and E. Cruwys. 1998. The photographs of H.G. Ponting. London: The Discovery Gallery.

Riffenburgh, B., L. Cruwys and H.J.P. Arnold. 2004. With Scott to the Pole: the Terra Nova expedition 1910-1913. The photographs of Herbert Ponting. New York, NY: Book Creations. 
Ryall, A., J. Schimanski and H.H. Wærp. 2010. Introduction. In: Arctic discourses. Newcastle-upon-Tyne: Cambridge Scholars Publishing: $\mathrm{x}-\mathrm{xxii}$.

Savours, A.M. 1974. Scott's last voyage through the Antarctic camera of Herbert Ponting. London: Sidgwick and Jackson.

Schmidt-Ott, F. 1952. Erlebtes und erstrebtes 1860-1950. Wiesbaden: Franz Steiner.

Senckenberg Nature Research Society. 1918. Jahrhundertfeier der Senckenbergischen Naturforschenden Gesellschaft, 22 November 1917. Frankfurt-am-Main: Senckenberg Nature Research Society. URL: http://archive.org/ stream/berichtdersencke4849senc\#page/n3/mode/2up, (accessed 31 May 2016).

Shibata, H. 2012. Lt. Shirase and the 1910-12 Japanese Antarctic Expedition. Japan Society Proceedings 149: $76-$ 95.

Shibata, H. and L. Dagnell. 2012. Southbound with the ice floes - a night in Antarctica with Shibata and Shirase. URL: http: //www.japansociety.org.uk/24360/southbound-with-the-ice/, (accessed 20 May 2016).

Shirase, N. and the Japanese Antarctic Expedition Supporters Association. 2011. The Japanese South Polar Expedition of 1910-12: a record of Antarctica (translators L. Dagnell and H. Shibata). Norwich: Erskine Press.
Stehr, A. 1903. Bericht über die Ballonaufstiege. In: von Richthofen, F. (editor). Die Deutsche Südpolar-Expedition auf dem schiff "Gauss" unter Leitung von Erich von Drygalski. Berlin: Mittler und Sohn: 173-181.

Stevenson, W.R. III. 2010. The spirit of adventure: Japanese exploration and the quest for the South Pole. Unpublished $\mathrm{PhD}$ thesis. Manoa: University of Hawai'i.

Sturken, M. and L. Cartwright. 2001. Practices of looking: an introduction to visual culture. Oxford: Oxford University Press.

Thomas, J. 1990. Show man: the photography of Frank Hurley. Canberra: National Library of Australia.

Wamsley, D. and W. Barr. 1996. Early photographers of the Arctic. Polar Record 32: 295-316.

Wilder, K. 2009. Photography and science. London: Reaktion Books.

Winter, F. 1900. Einiges über die Deutsche TiefseeExpedition. Frankfurt-am-Main: Senckenberg Nature Research Society: 45-59. URL: http://archive.org/stream/ naturundmuseum1900senc\#page/n0/mode/2up, (accessed 12 May 2016).

Wråkberg, U. 2007. The quest for authenticity in narratives of Northern Borderlands. Nordlit 22: 193-209.

Yusoff, K. 2010. Configuring the field: photography in 20th century Antarctic exploration. In: Naylor, S. and J. Ryan (editors). New spaces of exploration. London: IB Tauris: 52-77. 